\title{
Multiplex PCR for Detection of Genes Encoding Antibiotic Resistance in Staphylococcus aureus
}

\author{
S. Wilfred Ruban ${ }^{1}$, P. Raja ${ }^{2}$, Nithya Quintiol ${ }^{3}$, Govind Vemala ${ }^{4}$ and K. Porteen ${ }^{5}$ \\ ${ }^{1}$ Department of Livestock Products Technology, Veterinary College, Hebbal, Bangalore, \\ ${ }^{2}$ Department of Animal Biotechnology, ${ }^{3}$ Department of Veterinary Public Health and \\ Epidemiology, RIVER, Pondicherry and ${ }^{4}$ Department of Livestock Products Technology (Meat \\ Science), ${ }^{5}$ Department of Veterinary Public Health and Epidemiology, Madras Veterinary \\ College, Chennai, India \\ *Corresponding author
}

\section{A B S T R A C T}

\section{Keywords}

S. aureus,

Chicken meat,

Antibiotic

resistance gene, PCR.

Article Info

Accepted: 12 April 2017 Available Online: 10 May 2017
A study was carried out to evaluate the prevalence of genes encoding antibiotic resistance for commonly used antibiotics in poultry production in $S$. aureus isolated from Chicken meat marketed in Chennai City. A multiplex PCR was used for screening of $50 \mathrm{~S}$. aureus isolates for the presence of five genes viz., aacA-aphD (aminoglycoside), tetK and tetM (tetracycline resistance), $\operatorname{erm}(\mathrm{A})$ and $\operatorname{erm}(\mathrm{C})$ (macrolide-lincosamide-steptogramin B resistance). The results of the study revealed that of the 50 isolates screened all the isolates (100 per cent) carried either one of these resistance gene. Among the various genes either alone or in combination 48 isolates (96\%) carried tet $K$ gene, 44 isolates (88\%) carried aacA-aphD gene, 43 isolates $(86 \%)$ carried $\operatorname{erm}(\mathrm{C})$ gene, three isolates $(6 \%)$ carried tetM gene and none of the isolates carried $\operatorname{erm}(\mathrm{A})$ gene. It was evident that 37 of the isolates (74 $\%)$ carried three resistant genes followed 6 isolates with two resistance genes (12\%) and one isolate with only one gene. The study clearly indicated the prevalence of multidrug resistant $S$. aureus in retail chicken meat and its potential in transference of antibiotic resistance to the consumers. This multiplex PCR can be used as a simple, rapid and accurate assay for identification of antibiotic resistance profile and could be used for surveillance in epidemiological studies.

\section{Introduction}

Emergence of antimicrobial resistance in pathogens especially from foods of animal origin has been mainly attributed to widespread and indiscriminate use of antibiotics in control of infection as well as growth promoters (Swartz, 1997). In addition, increase in international travel and trade have facilitated the easy spread of these resistant isolates over different geographical locations even to locations where antibiotics are seldom used. Among the various pathogens of interest, $S$. aureus is an important opportunistic pathogen of greatest concern because of its intrinsic virulence and its capacity to adapt to different environmental condition (Waldvogel, 2000).

Staphylococcus aureus has been one of the most adaptive bacteria in the antibiotic era, which is well documented by its ability to 
quickly respond and develop a resistance mechanism to the existing and new antibiotic starting from penicillin, methicillin to the most recent antibiotics used in human and animal therapy (Pantosti et al., 2007). Antibiotic resistance in $S$. aureus is mainly due to acquisition of genes either by horizontal gene transfer or endogenous resistance. The majority of the genes responsible for the resistance to antibiotics are mainly located in the plasmids, transposon or phages. Hence, an understanding of the genes responsible for antibiotic resistance is of public health importance and at present such information is still very limited in India especially with respect to $\mathrm{S}$. aureus isolated from meat and me products in India. Hence, the present study was designed with the objective to evaluate the prevalence of genes encoding antibiotic resistance for commonly used antibiotics in poultry production in $S$. aureus isolated from Chicken meat marketed in Chennai City.

\section{Materials and Methods}

The approval of the Institutional Biosafety Committee of Tamil Nadu Animal and Veterinary Sciences University, Chennai was obtained for conduct of the study. A total of $50 \mathrm{~S}$. aureus isolated from retail Chicken meat marketed in Chennai, Tamil Nadu, India based on standard protocol (ISO standard 6888/1:1999) were used in the present study. The isolates were initially confirmed by biochemical test viz., catalase test, Mannitol fermentation, Coagulase and thermonuclease test as per standard protocol. The final confirmation was carried out based on PCR targeting пис (thermonuclease) gene.

\section{Polymerase Chain Reaction}

The genomic DNA was extracted by using DNA extraction kit (Qiagen) and the primers were custom synthesized. The sequences of the primers used for gene amplification are presented in table 1. Multiplex Polymerase chain reaction (m-PCR) for the detection of 5 antibiotic resistance genes was performed according to the methods described by Strommenger et al., (2003). Briefly, amplification reactions were performed in a $25 \mu \mathrm{L}$ mixture containing $12.5 \mu \mathrm{L}$ of $2 \mathrm{X}$ PCR master mix (Amplicon, Denmark), 5pmol of each primers and $2 \mu \mathrm{L}$ of DNA template and the final volume was adjusted to $25 \mu \mathrm{L}$ by adding nuclease free water. Amplification reactions were performed using a DNA thermal cycler (Master Cycler Gradient, Eppendorf, Germany) with the following program: Initial denaturation at $94^{\circ} \mathrm{C}$ for 3 min was followed by 30 cycles of amplification with $94^{\circ} \mathrm{C}$ for $30 \mathrm{~s}$, annealing at $55^{\circ} \mathrm{C}$ for $30 \mathrm{~s}$, and extension at $72^{\circ} \mathrm{C}$ for 30 sand final extension for 5 minutes at $72^{\circ} \mathrm{C}$. The PCR products were stained with $1 \%$ solution of ethidium bromide and visualized under UV light after gel electrophoresis on $2.0 \%$ agarose gel.

\section{Results and Discussion}

In the present study it was observed that of the 50 isolates screened all the isolates (100 per cent) carried either one of these resistance gene (Fig. 1). The PCR protocol followed amplified specific products as outlined by Strommenger et al., (2003). Among the various genes studied either alone or in combination 48 isolates $(96 \%)$ carried tetK gene and amplified 360 bp product and three isolates $(6 \%)$ carried tet $M$ gene, amplifying 158 bp product. The tet genes confers resistance to tetracycline are contained within conjugative transposons that can be transferred horizontally and expressed in both Gram-positive and Gram-negative bacteria. The results of the present study are in concurrence with the findings of Schmitz et al., (2001) and Jones et al., (2006), who observed higher prevalence of tet $K$ gene in 
majority of the S. aureus isolates (60-100\%). In addition Schmitz et al., (2001) opined that among the Methicillin sensitive isolates tet $K$ gene was the most prevalent tetracycline resistance determinant whereas in methicillin resistant $S$. aureus, tetM was most frequent gene.

In the present study, 44 isolates $(88 \%)$ carried $a a c A-a p h D$ gene and amplified $227 \mathrm{bp}$ product and similarly Nakaminami et al., (2008) also observed that $a a c A-a p h D$ gene was the frequently detected resistance gene in both the MRSA $(96.1 \%)$ and MSSA $(85.8 \%)$ isolates in Japan. The aacA-aphDgene encodes resistance to gentamicintobramycin-kanamycin or kanamycinneomycin (Rouch et al., 1987).

Table.1 Primers used in this study

\begin{tabular}{|c|c|c|c|}
\hline $\begin{array}{l}\text { Target } \\
\text { Gene }\end{array}$ & $\begin{array}{l}\text { Resistance } \\
\text { phenotype }\end{array}$ & Primer sequence (5'-3') & $\begin{array}{l}\text { Amplicon } \\
\text { size (bp) }\end{array}$ \\
\hline \multirow[t]{2}{*}{$a a c A-a p h D$} & \multirow[t]{2}{*}{ Gentamicin } & TAA TCC AAG AGC AAT AAG GGC & \multirow[t]{2}{*}{227} \\
\hline & & GCC ACA CTA TCA TAA CCA CTA & \\
\hline \multirow[t]{2}{*}{$\operatorname{erm}(\mathrm{A})$} & \multirow{2}{*}{$\begin{array}{l}\text { Erythromycin, } \\
\text { Clindamycin }\end{array}$} & AAG CGG TAA ACC CCT CTG A & \multirow[t]{2}{*}{190} \\
\hline & & TTC GCA AAT CCC TTC TCA AC & \\
\hline \multirow[t]{2}{*}{$\operatorname{erm}(\mathrm{C})$} & \multirow{2}{*}{$\begin{array}{l}\text { Erythromycin, } \\
\text { Clindamycin }\end{array}$} & AAT CGT CAA TTC CTG CAT GT & \multirow[t]{2}{*}{299} \\
\hline & & TAA TCG TGG AAT ACG GGT TTG & \\
\hline \multirow[t]{2}{*}{ tet $K$} & \multirow[t]{2}{*}{ Tetracycline } & GTA GCG ACA ATA GGT AAT AGT & \multirow[t]{2}{*}{360} \\
\hline & & GTA GTG ACA ATA AAC CTC CTA & \\
\hline \multirow[t]{2}{*}{ tetM } & \multirow[t]{2}{*}{ Tetracycline } & AGT GGA GCG ATT ACA GAA & \multirow[t]{2}{*}{158} \\
\hline & & CAT ATG TCC TGG CGT GTC TA & \\
\hline
\end{tabular}

Fig.1 PCR for amplification of Antibiotic Resistance Gene in S. aureus isolated from retail Chicken meat in Chennai (tetK- 360bp; erm(C)- 299 bp; aacA-aphD- 227 bp and tetM- 158 bp).

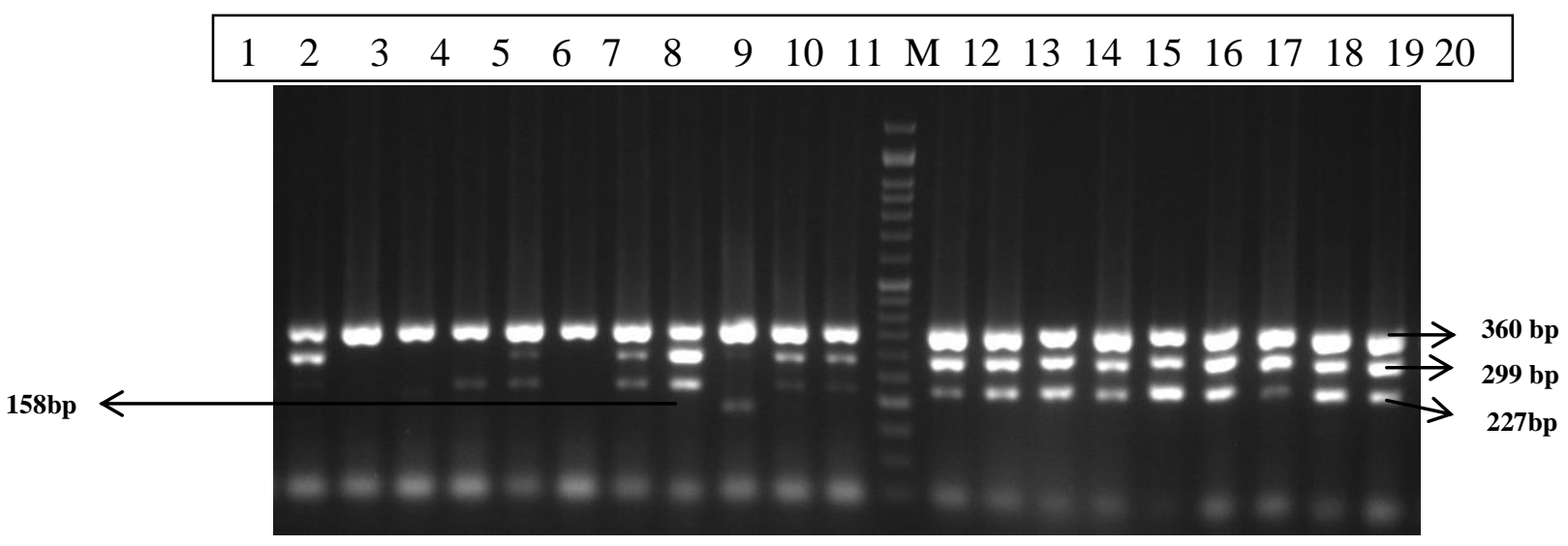

Macrolide resistance in S. aureus is mediated by one or more erm genes encoding a $23 \mathrm{~S}$ rRNA methylase. In the present study it was evident that 43 isolates $(86 \%)$ carried $\operatorname{erm}(\mathrm{C})$ gene amplifying $299 \mathrm{bp}$ product, and none of the isolates carried $\operatorname{erm}(\mathrm{A})$ gene.Similar expression of $\operatorname{erm}(\mathrm{C})$ gene has been documented by Nicola et al., (1998) and Lina et al., (1999). The results of the present study were contrary to the findings of Schmitz et 
al., (2000), who observed that the most prevalent gene was erm(A) followed by $\operatorname{erm}(C)$ in 67 and 23 per cent of the isolates respectively.

The present study clearly indicates that $S$. aureus isolated from the chicken meat marketed in retail outlets of Chennai carries multiple antibiotic resistant genes that confer resistance to commonly used antibiotics in human and animal therapy like Gentamicin, tetracycline and erythromycin. Hence, control strategies with respect to hygiene need to be put in place to prevent the spread of these multidrug resistant pathogens to the consumers.

\section{Acknowledgement}

The author duly acknowledges the Dean and Department of Livestock Products Technology (Meat Science), Madras Veterinary College, TANUVAS, Chennai for providing facilities for conduct of the research.

\section{References}

ISO 6888-1: 1999. Horizontal methods for enumeration of coagulase positive Staphylococci (Stahylococcus aureus and other species). Part 1: Technique using Baird-Parker agar medium. International Organization for Standardization, Geneva, Switzerland.

Jones, C.H., M. Tuckman and Howe, A.Y. 2006. Diagnostic PCR analysis of the occurrence of methicillin and tetracycline resistance genes among Staphylococcus aureus isolates from phase 3 clinical trials of tigecycline for complicated skin and skin structure infections. Antimicrob. Agents Chemother., 50: 505-10.

Lina, G., Quaglia, A., Reverdy, M.E., Leclercq, R., Vandenesch, F. and
Etienne, J. 1999. Distribution of genes encoding resistance to macrolides, lincosamides, and streptogramins among staphylococci. Antimicrob. Agents Chemother., 43: 1062-1066.

Nakaminami, H., N. Noguchi, M. Ikeda, M. Hasui, M. Sato, S. Yamamoto, T. Yoshida, T. Asano, M. Senoue and Sasatsu, M. 2008. Molecular epidemiology and antimicrobial susceptibilities of 273 exfoliative toxinencodinggene-positive Staphylococcus aureus isolates from patients with impetigo in Japan. J. Med. Microbiol., 57: $1251-1258$.

Nicola, F.G., L.K. McDougal, J.W. Biddle and F. and Tenover, F.C. 1998 Characterization of erythromycinresistant isolates of Staphylococcus aureus recovered in the United States from 1958 through 1969. Antimicrob. Agents Chemother., 42: 3024-7.

Pantosti, A., A. Sanchini and M. Monaco. 2007. Mechanisms of antibiotic resistance in Staphylococcus aureus. Future Microbiol., 2(3): 323-334.

Rouch, D.A., M.E. Byrne, Y.C. Kong and Skurray, R.A. 1987. The aacAaphD gentamicin and kanamycin resistance determinant of Tn4001 from Staphylococcus aureus: expression and nucleotide sequence analysis. J. Gen. Microbiol., 133: 30393052.

Schmitz, F.J., A. Krey and Sadurski, R. 2001. European SENTRY Participants: Resistance to tetracycline and distribution of tetracycline resistance genes in European Staphylococcus aureus isolates. J. Antimicrob. Chemother., 47: 239-40.

Schmitz, F.S., Sadurski, R., Angela Kray, Mechthild Boos, Roland Geisel, Karl Köhrer, Jan Verhoef and Ad C. Fluit. 2000. Prevalence of macrolideresistance genes in Staphylococcus 
aureus and Enterococcus faecium isolates from 24 European university hospitals. J. Antimicrob. Chemother., 45(6): 891-894.

Sekiguchi, J., T. Fujino and Saruta., K. 2004. Prevalence of erythromycin-, tetracycline-, and aminoglycosideresistance genes in methicillinresistant Staphylococcus aureus in hospitals in Tokyo and Kumamoto. Jpn J. Infect. Dis., 57: 74-77.
Swartz, M.N. 1997.Use of antimicrobial agents and drug resistance. N. Engl. J. Med., 337: 491-492.

Waldvogel, F.A. 2000. Staphylococcus aureus (including staphylococcal toxic shock).In Principles and practice of infectious diseases. G.L. Mandell, J.E. Bennett, and R. Dolin, editors. Churchill Livingstone. Philadelphia, Pennsylvania, USA, 2069-2092.

\section{How to cite this article:}

Wilfred Ruban, S., P. Raja, Nithya Quintiol, Govind Vemala and Porteen, K. 2017. Multiplex PCR for Detection of Genes Encoding Antibiotic Resistance in Staphylococcus aureus. Int.J.Curr.Microbiol.App.Sci. 6(5): 1052-1056. doi: https://doi.org/10.20546/ijcmas.2017.605.114 